\title{
Article \\ Tiger King and the Exegesis of COVID-19 Media Coverage of Nonhuman Animals
}

\author{
Claudia Alonso-Recarte
}

check for updates

Citation: Alonso-Recarte, Claudia. 2022. Tiger King and the Exegesis of COVID-19 Media Coverage of

Nonhuman Animals. Journalism and Media 3: 99-114. https://doi.org/ 10.3390/journalmedia3010008

Academic Editors: Carrie P. Freeman and Núria Almiron

Received: 10 December 2021

Accepted: 10 January 2022

Published: 20 January 2022

Publisher's Note: MDPI stays neutral with regard to jurisdictional claims in published maps and institutional affiliations.

Copyright: (C) 2022 by the author. Licensee MDPI, Basel, Switzerland This article is an open access article distributed under the terms and conditions of the Creative Commons Attribution (CC BY) license (https:// creativecommons.org/licenses/by/ $4.0 /)$.
Departament de Filologia Anglesa i Alemanya, Universitat de València, 46010 Valencia, Spain; Claudia.Alonso@uv.es

\begin{abstract}
Beginning with the premise that the media participates in the manufacturing of the societal consent that enables and perpetuates the systematized exploitation of nonhuman animals, this article explores how media coverage of such nonhuman animals (and of wildlife in particular) during the COVID-19 crisis may influence our consumption of popular entertainment in a way that centralizes the discussion on the implications of established speciesist practices. I specifically focus on the impact of the first season of Netflix's successful docuseries Tiger King: Murder, Mayhem, and Madness, directed by Eric Goode and Rebecca Chaiklin, which was released in March 2020, a key moment in the worldwide management of the pandemic. Tiger King has generated significant controversy because of its languid commitment to a solid conservationist message and to the paradigm of animal advocacy documentaries. However, understanding how and why nonhuman animals were considered newsworthy by COVID-19 media provides us with some interpretative keys through which to reapproach the significance of the show. Analyzing the series' main themes and motifs in light of the media's narratives on lockdown, wildlife, and human interference over nature allows us to continue exploring methodologies through which to question the multiple anthropocentric discourses that structure and order societal consent to the existence of zoos.
\end{abstract}

Keywords: Tiger King; COVID-19 media; popular culture; zoos; quarantine; captive wildlife

\section{Introduction}

In 2020, as human societies worldwide shut themselves in their homes following governmental recommendations or obligations to decelerate the spread of coronavirus, the media voraciously dove into the exploration of the many stories that could compound an overall sociocultural narrative of the health crisis. In this unprecedented global scenario in the age of modern technology and communication, nonhuman animals gravitated towards the center of media attention in order to address the anxieties, uncertainties, and excess of information and misinformation surrounding the pandemic. This paper explores how discourses, meanings, and connotations associated with nonhuman animals during the pandemic may have influenced audience perceptions on wildlife ${ }^{1}$ in Netflix's hit sevenepisode docuseries Tiger King: Murder, Mayhem, and Madness, directed by Eric Goode and Rebecca Chaiklin. The first season of Tiger King was released in March 2020, coinciding with the beginning of lockdown in the United States and around the world, and would become one of the most viral, binge-watched shows during quarantine, with dozens of millions of viewers in only the first month. The documentary, which was intrinsically problematic in terms of its treatment of captivity narratives, seemed structurally torn between an unapologetic absorption of formulaic entertainment and an alleged conservationist agenda. However, the pop culture phenomenon that it became, I argue, should not preclude its historization within a highly convulsed era in which coronavirus was redefining human interactions and spatial encounters with nonhuman animal others. The massive popularity of Tiger King during as extraordinary a time as the pandemic begs the question as to whether such new ways of looking at animal otherness, wildlife, and the spaces they occupy invite 
alternative "readings" of the series' representation of the decadent American zoo culture and of the threat of extinction.

\section{The Anthropocentric (In)visibility of Nonhuman Animals}

The exegesis of documentaries is irreparably bound to the historical context and cultural zeitgeist from which they emerged and into which they are released. Tiger King was five years in the making, and so the type of environmental concerns with wildlife that the show reflected (or, as some critics would argue, sidestepped) answered to preCOVID anxieties and sensibilities. By the late 2010s, climate change, accelerated loss of biodiversity, the threat of contaminants such as plastics, the depletion of oceanic ecosystems, and the overall umbrella concept of the Anthropocene had permeated public discussions and entered many countries' national and international political agendas for compromise. The extent to which the media was effective in leading to action to counteract problems of such magnitude, however, remains questionable. What seems clear is that a narrative pattern had been shaping; one in which discourses of extinction were authenticated through scientific authority and often expressed with overwhelming lists of threatened ecosystems and ecological disasters:

Indeed, the 2010s mark the decade when the impacts from climate change became unmistakable, at least for any objective-minded observer. As temperatures rose, Arctic sea ice melted far faster than models had predicted. The world's coral reefs suffered widespread and devastating bleaching events. And regions around the world grappled with some of the costliest, deadliest, and most extreme droughts, hurricanes, heat waves, and wildfires in recorded history. (Temple 2019, para. 21)

Despite pre-COVID-19 public discussions on global warming, mainstream journalistic connections between the ecological crisis and the systemic unethical treatment of nonhuman animal others had been disproportionally scant. After all, media and communication have been instrumental in the manufacturing of societal consent for the industrialized and systematized abuse of nonhuman others (Almiron 2016, p. 27), and what little attention the media did pay to animal abuse tended "to support, rather than challenge, hegemonic speciesism in a number of ways" (Taylor 2016, p. 42). As Spiehler and Fischer add, "the public isn't very concerned about the plight of animals—or is concerned, but has a high tolerance for cognitive dissonance" (Spiehler and Fischer 2021, p. 2). The invisibility of nonhuman animals in capitalist systems has been long noted by John Berger (Berger [1980] 2009) and Carol Adams (Adams [1990] 2015): the former famously discussed how nonhuman animals have been surrogated by the consumable, cultural representations that we have of them, while the latter theorized about the piecing of their bodies into edible fragments, rendering the actual nonhuman animal, the "absent referent", unworthy of visibility or moral consideration. The normalization of mass consumption of nonhuman others has been further validated by media practices that both dictate and naturalize their conception as commodities to be objectified or commercialized with.

Certain types of narratives that deal with nonhuman otherness bear a complex connection to the manufacturing of consent. Such is the case of documentary films. Wildlife documentaries, for instance, have a long history of nonhuman animal advocacy in television culture and have sparked all sorts of discussions pertaining to the ethics of wildlife representation (Bousé 2000; Chris 2006; Horak 2006; Mills 2010, 2012, 2017; Mitman 2009). In basic terms, these films are characterized by the representation of wild animals in their habitats with minimal human intervention, with the object of reflecting "natural" instincts and behaviors. The genre, however, has been exposed on a number of occasions for its manipulation of the time and spaces in which the represented nonhuman animals function. In addition, the genre's claims of advocacy must be contrasted with the use of a rhetoric and technique that, on the other hand, strengthen the collective consent to objectify nonhuman animals. Wildlife documentaries' overt reflections of mainstream ideology (Chris 2006, p. xix) and heteronormativity and monogamy (Mills 2012) function under a consensual assimilation of anthropomorphism that informs our own human cultures, frequently dis- 
regarding the factors and findings that may justify the conceptualization of nonhuman animals as sentient subjects worthy of moral consideration.

Tiger King, in any event, does not qualify as a wildlife documentary per se, and as we will see, its intrinsic connections to nonhuman animal advocacy documentaries are fragile. In the twenty-first century, partly as a response to the growing awareness of the perils of the Anthropocene and the need for a market to refer to these issues, there has been a notable increase in the production of these so-called animal advocacy (or even activist) documentary films that have countered mainstream media's manufactured consent of nonhuman animal exploitation. Ranging from more welfarist to more deontological approaches, or even treating animal protection as primarily beneficial to human interests, these documentaries have resorted to methods such as undercover footage, strategic use of authority figures, and the sensuous, raw representation of nonhuman animal suffering in the hands of humans and their industries through visuals and soundscapes. As Loy states, "[b]y engaging strategically and meaningfully in this public discourse [on nonhuman animal exploitation], advocates can help alter the anthropocentric paradigm of our times and lay the foundation for the transition to a more eco-centric model" (Loy 2016, p. 221). Among the many titles, we may find documentaries imploding agriculture, farming, and the food industry and exposing myths about proper nutrition (Super Size Me (Spurlock 2004); Food, Inc. (Kenner 2008); Cowspiracy: The Sustainability Secret (Andersen and Kuhn 2014); Lucent (Delforce 2014); The Game Changers (Psihoyos 2018)). There are also documentaries such as Earthlings (Monson 2005) and Dominion (Delforce 2018) that construct their shock tactics with the accumulation of footage of wanton cruelty and abuse in a number of industries (food, clothing, entertainment, tourism, the pharmaceutical and medical research industries, etc.) Others build their criticism against such industries by focusing on the individuality of one particular victim or species. Coperthwaite's Blackfish (Coperthwaite 2013) and Marsh's Project Nim (Marsh and ir 2011), for instance, respectively articulate anticaptivity messages through the tragic stories of a Sea World orca and a chimpanzee used for research in language and grammar acquisition. Schatz's short film An Apology to Elephants (Schatz 2013) depicts the history of the exploitation of elephants in the entertainment industry, and Psihoyos's award-winning The Cove (Psihoyos 2009) portrays the massacre of scores of dolphin pods in Taiji, Japan. Other films are case studies of the destruction of particular habitats and the massive disappearance of wildlife (Virunga (von Einsiedel 2014); Seaspiracy (Tabrizi 2021)), and others focus on the work of acknowledged activists (such as Jo-Anne McArthur in Marshall's The Ghosts in Our Machine (Marshall 2013)) and their criminalization (Your Mommy Kills Animals (Johnson 2007); The Animal People (Hennelly and Suchan 2019)). Yet others focus on emphasizing the interspecies similarities with humans, depicting the legal conundrum (Unlocking the Cage (Hegedus and Pennebaker 2016)), or the act of "becoming" the nonhuman animal other and being invited into "their" world (My Octopus Teacher (Ehrlich and Reed 2020)). These are just part of a shortlist of productions that aim to educationally shatter our active and our passive involvement in the manufacturing of consent. As Claire Parkinson [Claire Molloy] contends in her landmark study Popular Media and Animals, "not all news media representations trivialize animals. Public interest in conservation, animal welfare, animal rights, ethics and the environment has prompted the inclusion of animal stories that blur the line between soft and hard news in newspapers and television" (Molloy 2011, p. 7). Whether Tiger King merits being categorized as an animal advocacy documentary is a reasonable debate that will be further explored throughout this paper. For now, it is suffice to say that its reception must be regarded from the point of view of how it compares to the narratives purported in these types of films.

In addition, beyond observations as to the structure and genre of the series and how these might strengthen or challenge the manufacturing of societal consent, what this paper seeks is to understand how media discourses and stories on nonhuman animal otherness during the pandemic may have filtered themselves into the Tiger King narrative, offering metaphors and interpretations that the creators of the show could not have anticipated. The anthropocentric urgency of the pandemic, with its fundamental focus on saving human 
lives, in many ways pushed the discourse of a perishing world to the forefront, rendering evident how the mismanagement and destruction of the environment had caused the outbreak of the virus. In their study on the UK's leading media coverage of nonhuman animals as COVID-19 vectors, Hooper et al. refer to these as the "it's our fault" narratives, based on "a presumptive concern about the human role in dramatically affecting the lives of animals in the wild through an emphasis on littering, the human spread into traditionally understood animal spaces, or a broader concern about the environmental impact of the pandemic" (Hooper et al. 2021, p. 12). These types of "we-brought-this-on-ourselves" patterns became part of the scaffold of the narratives that were to define the global health crisis, providing it with a set of images and an identity that could in time consolidate a historiographic record of the period. To focus on the health of the planet was in the interest of self-preservation first, and so mainstream media's manufacturing of consent when it came to the exploitation of nonhuman animals remained for the most part intact at its core. What did change in the media's coverage of nonhuman animals was the reason why they were newsworthy enough to figure in different types of stories and headlines that compounded the sociocultural narratives of the crisis. Long accustomed to a cultural apparatus of modernity in which they have "'disappeared" and have been replaced by commodified consumables (Berger [1980] 2009), nonhuman animal bodies became, in a way, a very "real" thing-one with very real consequences.

By claiming that the media's coverage of nonhuman animals since the beginning of the pandemic has made them more "visible", I do not mean to convey that this has been to favor their consideration as sentient beings: although some progress may have been made in this regard, the overall focus on anthropocentric interests, as mentioned above, mostly overpowered arguments that called for a cautionary protection of the environment and management of natural resources for the sake of the nonhuman animals themselves. What I mean is that, although the media presupposes representation in and of itself, the nonhuman animals that were covered by these reports were done so on the basis of their biological significance precisely because their bodies, their physiologies, and how humans process them and make them consumable commodities had direct consequences over human health. The "absent referents" that were made visible by the media were not sentient nonhuman animals with complex subjectivities - they were embodied liabilities that had to be properly monitored and manufactured to avoid grand-scale risks for humans. In the words of environmental and business historian Joshua Specht,

COVID-19 is a reminder of our embeddedness in the animal world. Despite the conceptual boundaries we draw between human and nonhuman, we are in intimate contact with animals everywhere in the world... Animals make our world, whether visible or not. And sometimes that centrality has fundamental consequences. (Way et al. 2020, p. 468)

Spiehler and Fischer argue that indirect animal rights activism that focused either on wet markets in particular or on the larger, transnational issue of intensive farming ran the risk of ultimately backfiring and servicing corporative monopolization of nonhuman animal agriculture, as well as of fueling racist rhetoric, however unintentionally. Beyond the validation or counterclaims to their discussion, what I would like to draw attention to is the fact that indirect forms of activism have been, it seems, rather prevalent throughout the pandemic. By indirect activism, Spiehler and Fischer refer to forms of activism that appeal to public interests but that are designed to accommodate the activist's primary agenda-to abolish nonhuman animal exploitation:

[I]t's indirect in the sense that the issue that's supposed to 'hook' the audience isn't the one that's the primary motivation for the activism, even if it's an issue about which the activist is genuinely concerned; instead, it's an issue she hopes to use to motivate others to act in ways that fit with her primary objective. (Spiehler and Fischer 2021, p. 2) 
The very need to resort to indirect activism is a confirmation of the extent to which anthropocentric concerns underlie the damage control of the pandemic. In other words, despite the fact that nonhuman animals gain prominence in COVID-19 narratives, it does not mean that their presence indicates a shift regarding their moral consideration. As advocates employing indirect forms of activism suggest, according to Spiehler and Fischer, the public's primary concern is with food safety and the effects of zoonotic diseases on humans, not with nonhuman animal suffering or environmental degradation. Mainstream COVID-19 media, therefore, catapulted nonhuman animals as embodiments that were newsworthy insofar as they were evidence of human self-sabotage. As Yin et al. ascertain, "[w] hile humans and animals were simultaneously harmed by COVID-19, ethical concerns for human suffering were prioritized" (Yin et al. 2021, p. 1426).

In what I hope to be a fruitful gesture, what I intend to convey in this study is that for all the anthropocentric interests that motor COVID-19 media stories on nonhuman animals, we may still reappropriate our roles as consumers and interpreters and find exegetical paths through which to make eco-centric concerns viable. In other words, being a responsible consumer of media coverage involves being an active critic, not a passive recipient, and in that exercise of responsibility we would do well to make room for the study of how media discourses can potentially absorb narratives in which anthropocentric and nonhuman-animal-centered issues can coexist and converge. The focus on Tiger King is particularly strategic in this regard because examining its structural narratives and audiovisual rhetoric against the backdrop of COVID-19 media is not just an active stand against the purism of anthropocentrism, but also against the viral, mainstream reception of a show that all-too-clearly spreads the comfort zone of collective manufactured consent. By contextualizing the docuseries in the wider discursive frameworks of COVID-19 media coverage of nonhuman animals, we may instrumentalize stories of the pandemic and turn them into devices and mechanisms through which to reassess the narratives purported by the show, and thus offer alternative and plausible readings that can be integrated into popular culture.

\section{Watching Tiger King during Lockdown}

On 20 March 2020, Netflix released the seven-episode docuseries Tiger King: Murder, Mayhem, and Madness, directed by Eric Goode and Rebecca Chaiklin. The show became an unexpected hit-Nielsen ratings estimated that more than 30 million people watched it in the first ten days, as word-of-mouth spread all over social media about a documentary on the gun-toting, eccentric, violent, and double-crossing individuals that kept, bred, abused, and exploited large cats (and other captive wildlife) in their poorly managed private and roadside zoos. A vivid and tongue-in-cheek portrayal of Trump's rural white America, the show capitalized on what seemed like an endless source of outrageous characters that populated the business, topped off by Joe Exotic (Joseph Maldonado-Passage), the gay, guncrazed, former owner of the Greater Wynnewood Zoo in Oklahoma who sports a bleached mullet and has a penchant for vulnerable young men. As if echoing nineteenth-century freak shows and the publicity tactics of P. T. Barnum, the docuseries paraded, through interviews and preposterous footage, the bizarre and outlandish likes of the meth addicts and their enablers, megalomaniacs, unofficial murder suspects, con artists, ex-convicts, and felons that feuded against one another, culminating with a murder-for-hire subplot that leads to Exotic's 22-year prison sentence. "All of these characters and behaviors are approached with the simplified, pleasurable spectacle of meme culture" (Lagerwey and Nygaard 2020, p. 561). Even the inclusion of disabled zoo staff and characters that identified as queer seemed to serve an agenda of making poverty and trauma entertaining, as episodic narratives drew on the climaxing tensions of the violent relationships and documentary conventions slipped into techniques reminiscent of reality television and true-crime serials.

As critics of the show soon made clear, the series' indulgence in parodic and melodramatic character portrayal played well with binging audiences, but overshadowed the contextual problem that had, as admitted by director Eric Goode himself, been the orig- 
inal reason for the making of the documentary: the fact that there were between 5000 and 10,000 tigers held captive in America, while fewer than 4000 remained in the wild. The conservationist message quickly became diluted, as the documentary fed into the narcissism and instability of the personalities only to occasionally show or remark on the cruel and insalubrious conditions in which nonhuman animals were kept in zoos (the opening and closing sequences of the documentary, interestingly enough, do dedicate a few minutes, as if apologetically, to the urgent situation that tigers face as an endangered species). For the most part, the documentary fell frustratingly short from centralizing the discussion around proper conservation. Among other things, it nurtured the narrative of private and roadside zoos being similar to accredited types of sanctuaries, such as the one owned by Exotic's archenemy, Carole Baskin. A prominent piece against the series was Rachel Nuwer's article for The New York Times a couple of weeks after Netflix's release. Significantly titled "Why Tiger King Is Not Blackfish for Big Cats", the article pointed out that not only did the series fail to address the urgent situation of captive wildlife more adamantly, but that it further threatened to worsen the situation by creating "a glamour around tiger ownership, and assign[ing] a folk heroism to the 'Joe Exotic' personality that could set back efforts to end the abuse and ownership of big cats" (Nuwer 2020, para. 8). Indeed, certain statements made by right-wing conservatives downplayed and infantilized the wildlife conservation issues at stake. When rumors started circulating that Joe Exotic was fishing for a presidential pardon, Donald Trump Jr. declared on air that "You know what the real tragedy is right now from that whole show? None of us knew that you could have had a pet tiger for like two grand" (as cited in Flood 2020, para. 13). The flooding amount of Internet memes flaunting statements and expressions that were popularized by the docuseries further attested to the trivialization of wildlife preservation. These collective actions evince the extent to which Steve Baker's claim that "the animal is the sign of all that is taken not-very-seriously in contemporary culture; the sign of that which doesn't really matter" (Baker [1993] 2001, p. 174) still holds true. Writing for the Orlando Sentinel, Fokidis chimed into criticism of the show, noting the lack of "commentary from any real wildlife conservation experts", and the overexposure to the reasoning of the breeders and owners that make up "the show's main personalities" and that "are misleading and just plain wrong" (Fokidis 2020). Most bewildering was perhaps the popular backlash that Carole Baskin faced and the amount of support that Joe Exotic received from viewers (and even celebrities) who were convinced that he had been wrongfully accused of attempting to orchestrate a murder-for-hire. As written in the Los Angeles Times, "[b]inge-watching justice is officially a thing" (Ali 2020, para. 15). The second season, which premiered on 17 November 2021, followed suit with five episodes in which the criminal schemes only seemed to grow larger, and in which it appeared as if both "cast" and show creators desperately tried to cling to season 1 memorabilia of shocking imagery and statements in order to capitalize on the remnants of the series' popularity. Critics such as Lopez (2021) condemned the show's ongoing cynical stance on endangered species, recalling the pointlessness of showing footage of animal abuse in a scattered narrative agenda.

To get back to season 1, despite the discursive flippancy and the overt focus on the human characters, the scattered details about nonhuman animals' miserable lives in zoos and other types of facilities may, I argue, have become particularly noticeable by viewers on account of the circumstances surrounding the pandemic. Just nine days before Netflix released the series, the World Health Organization had declared COVID-19 a pandemic. In the United States, crisis management escalated with the President's declaration of a National Emergency on March 13 and the issuing of a travel ban on non-Americans coming from a list of European countries. California became the first state to issue a mandatory stayat-home order on March 19, and in the following weeks the majority of the states followed with either mandatory or advisory orders. From late February to April, countries around the world issued their own orders and regulations with varying degrees of restrictions, with the second half of March having been a particularly determining period for lockdown in Europe, North and South America, and Africa (Coronavirus 2020). 
It seems reasonable to think that Tiger King would not have enjoyed the success that it did had its release been scheduled differently or had there not been a pandemic. The documentary came out at a time in which countless narratives, hypotheses, theories, and debates on coronavirus saturated the media, and Tiger King offered the kind of digestible entertainment formula that provided a fast and easy way to escapism. These escapist strategies should not be, however, easily dismissed. A study by Grondin et al. (2020) showed that the isolation and loneliness experienced during quarantine had an effect on psychological perceptions of time. Among other observations, they contended that the loss of temporal landmarks, the uncertainty about the duration of lockdown and the return to "normal", and the anxiety that scores of people experienced had a profound effect on the organization of one's time and one's life at large. To cope with this, the WHO recommended self-imposed forms of organization and routines, directing attention to time elsewhere in order to make the duration appear as short as possible. At the same time, the saturation of the media contributed to the impression that the beginning of quarantine was distant. In this context of disturbed perceptions of time, watching TV series and binging on screens could provide some sense of routine and the solace of an escapism from the overwhelming excess of information and misinformation that was systematically consumed and that offered confusing (or at least indefinite) predictions regarding a vaccine, the end of quarantine, or the flattening of the curve. This might explain why a docuseries with apparently nothing to do with the urgency of the pandemic might have met such widespread success. As Michelle Orange put it in a critical commentary published in $V Q R$, "I knew less about the show ... than I did about the haste with which people were choking it down ... Everyone was inside now. The need to watch a lot of something and then make fun of it appeared vital and universal, a rare source of unity" (Orange 2020, p. 204). I argue that for all the strife for evasion, however, Tiger King still operated on an imagery, symbols, and indexes that compelled viewers to think about the pandemic and its effects-in other words, shows and other entertainment-related activities were instrumental in carving out the subnarratives that defined the experience of quarantine, in the same way that the pandemic itself informed the way such output was assimilated and consumed.

For one thing, as argued earlier, nonhuman animals were becoming newsworthy in a number of ways in which, although anthropocentric interests remained prevalent, their (in)visibility was framed within the contextual landscapes of the pandemic. As embodiments, they had had a determining role in the outbreak, its evolution and its management, whilst their spatial connections to humans were being reassessed and appreciated under the lens of a newly found collective awareness as to their existence. Watching representations of captive wildlife within the context of confinement and isolation presented the unplanned opportunity to empathize with nonhuman animal subjects whose movements were curtailed by cages. "The space which they inhabit is artificial", Berger states. "Hence their tendency to bundle towards the edge of it ... Nothing surrounds them except their own lethargy or hyperactivity. They have nothing to act upon-except, briefly, supplied food and-very occasionally-a supplied mate" (Berger [1980] 2009, p. 35). Caged wildlife shed some interpretative light into the sense of dullness and demotivation that vast numbers of quarantined people experienced, as their psychological time in the nothingness of fleeting actions made thinking about time unbearable. In the same way that caged wildlife fall into pointless stereotypies such as pacing back and forth, so do people force themselves into routines and escapist activities to pass the time. During lockdown, a number of memes connecting quarantine with the framing of wildlife in zoo cages circulated through social networks. One such example featured four pictures of a panda bear sitting on his/her haunches in a bare cement cage staring aimlessly or with his/her head on the wall. The caption reads: "Now you know how the animals in a zoo feel!" Another meme featured pictures of a brown bear also sitting dully on the corner of the cement-floored cage, an orca floating on his/her side in a tank that is obviously too small, an elephant leaning his/her head against a cement wall, and a close up of what seems like another elephant pressing his/her tear-eyed face against bars. "So, you're sick of isolation?" states the caption. 
Quarantine and isolation, in other words, precipitated comparisons with other forms of existing in time and space. In the same way that the media flourished with reports on the lessons that astronauts could teach us about managing solitude (Kluger 2020), so did we perhaps begin to reconsider the irreparable damage done to nonhuman animals kept in zoos by restricting them from multiple types of freedoms. Zoos have, of course, a long history in the visual materialization of imperialistic and colonialist practices through which to overpower, alienate, and frame everything and anything falling in the category of "other". Scholarly histories of zoos (Hoage and Deiss 1996; Hanson 2002) and of their exegetical possibilities (Malamud 1998) have examined the spatial and visual dynamics of the exhibitionism of wildlife that is aimed at defining and representing the power of the culture that carries out the act of caging. One of the things that Malamud notes about zoos is that they

Perpetuate a restrictive popular cultural sense of nature. Predominantly, audiences experience the zoo's collection of captive animals not as a small sample of much larger and more varied wild populations, but as the best example they can ever expect to see. (Malamud 1998, p. 35)

Nonhuman animals caged in zoos, in other words, are museum pieces, synecdoche of a world that is slowly disappearing, slowly dying. In the follow-up special to the first season of Tiger King, in which TV personality Joel McHale interviews, during quarantine, several of the "cast" members, an ex-worker of the GW Zoo states that

I never thought that [tigers] should be kept in captivity. But I knew the reality of it and the reality of it is, they cannot be returned to the wild. And there's not much of a wild for them to return to. (Goode and Chaiklin 2020, Ep. 8, 18:16)

This position has been very prominent in the articulation of discourses that elevate the role of zoos as sanctuaries of sorts, where the preservation of wildlife is marketed as the prime purpose. Horak identifies this type of argumentation in narratives embedded in multiple wildlife documentaries. Describing Awesome Pawsome, a 2000 Animal Planet program in which four tiger cubs are raised as domestic cats, he notes that "[ $t$ ]he rescue of tigers from extinction, this program, too, tells us, is a matter of setting up zoos and wildlife parks" (Horak 2006, p. 472).

Tiger King does not proactively endorse these sorts of views that cleanse the public image of zoos, but it does provide the big cat owners who think that way with ample space in which to develop their ideas. The ethics of human intervention in the management of wildlife is, at the same time and as I have suggested above, one of the motifs that structured the newsworthiness of nonhuman others during the pandemic. Quarantine, specifically, led to two types of stories about wildlife: those about how the welfare of wild and feral animals had been compromised by the absence of humans and those about how that same absence had proven favorable for many species. The narrative of how zoos rehabilitate and preserve endangered species fits within the first group's emphasis on the benefits of human monitoring and surveillance. According to these stories, dependence on the provision of food, care, exercise, and protection is instrumental for the welfare of countless nonhuman animals. What is interesting about such reports is that many of the proclamations about the vulnerability of nonhuman animals in the face of human absence were themselves contested by evidence brought up in subsequent stories. Deutsche Welle (DW), Germany's international broadcaster, for instance, reported how a German animal rights charity called for the need to tend to city pigeons whose main source of food (leftovers and scraps) had disappeared and who faced the real threat of starvation (Martin 2020). Other organizations worldwide, such as the Fundación para el Asesoramiento y Acción en Defensa de los Animales (FAADA) in Spain, however, reassured concerned citizens that pigeons and other urban birds had a high capacity for adaption to the new circumstances and would be able to find food on their own (FAADA 2020). Somewhat contradictory predictions and evidence also surrounded discussions about the effects on wildlife tourism and conservation. In May 2020, the BBC reported a surge in poaching activities in Southeast Asia and in Africa, 
mainly as a result of the rural migration of populations unable to support themselves in the cities, but also as a consequence of the diminished activity of rangers and even tourists who functioned as inadvertent guardians (Matthews 2020). On the other hand, press reports from 2021 claimed that the pandemic had led to a decrease in poaching of certain threatened species such as the rhino in South Africa, as the lack of tourists allowed better visibility of poachers, whose movements were under the radar (BBC 2021; Frost 2021). Having in mainstream media contesting narratives about the effects of quarantine on wild animals' welfare, I argue, favors the questioning of naturalized arguments pertaining to strategies for conservation, such as the insistence on zoos as the only viable space in which to protect endangered species. As long-time anti-zoo advocate Malamud writes, "[t]he zoo's ecological messages are false, and it is therefore unethical for zoos to abet the dissemination of this disinformation" (Malamud 2012, p. 128).

At the same time, COVID-19 media discourses that fed into narratives of loss and death exacerbated the threat of extinction in other ways. The numbers and estimations of the millions of human deaths from coronavirus, the fading of activities and behaviors once considered "normal", and the replacement of face-to-face modes of communication and affection with rituals and forms of mediation that adjusted to the demands of social distancing all signified the obsolescence of what was once common and familiar. In this context of sensibilities, nonhuman animals categorized as threatened and endangered species have acquired a discursive significance as emblems of the loneliness and the solitude of extinction. However, what may be disappearing is not just the endangered animals, but some part of the savage capitalist subculture that commercializes them. The critical approach that Tiger King makes to zoos, however flawed in so many ways, may in this way also be integrated within discourses of extinction that signify on the disappearance of an industry that seems long past its ethically sound historical momentum. The pandemic's slow assimilation of disappearance and re-envisioning of the "new normal" assist with the interpretation of tigers as outdated imagery from a culture of domination that, through manufactured consent, has systematically marginalized and exploited them. In this sense, as a show streamed during quarantine, Tiger King may also have contributed to naturalizing and collectively easing into a much-needed cultural change regarding wildlife management and the extinction of zoos, and the Baskins' strife to pass the Big Cat Public Safety Act may be regarded as a venture that complements the shifts towards the "new normal".

Framed against pandemic-related discussions on nonhuman animals, Tiger King could hence offer some insight into an interpretative space beyond what the show, with its clear drive towards entertainment, formally suggested. The very subject matter of nonhuman animals held in zoos was dissonant with the set of stories that celebrated how the absence of humans had led to flourishing wildlife. These were mainly media stories on how the emptied and silent urban spaces were being transited by wildlife. As Hockenhull et al. note,

the rapid reduction in human activity (and the associated noise, traffic, and pollution) brought with it the opportunity for global wildlife to fill the voids left behind and exploit the environs that the presence of humans and/or their associated pollution had previously rendered inaccessible. (Hockenhull et al. 2021, pp. 1-2)

Whether true or false, such reports "gave people across the globe positive news and pleasure at a time of great uncertainty" (Hockenhull et al. 2021, p. 2). The aesthetic effect of such sightings led to a revision of the extent to which divisions between cultural and natural spaces were artificial constructs intended to allocate nonhuman animals in spaces that were historically and politically deemed as heterogeneous to human society. Others claimed that these forms of "trespassing" were not new, and that it was just the elimination of human distractions that had made the nonhuman animals more visible as occasional occupants of urban spaces: "While it is possible that wildlife claimed deserted streets and parks during the shutdown, the reported spike in sightings could simply be due to an increase in observations of wildlife that were always there" (Zellmer et al. 2020, p. 2). A random sample of reports considered to be newsworthy include that of how a 
fox was spotted trotting down Downing Street (National Geographic en Español 2020); photographic galleries of nonhuman animals taking the streets of Tel Aviv, Istanbul, Nara, Mar de Plata, London, Venice, or New Delhi, among many other cities (The Guardian 2020; Chalasani 2020); or the reporting of scientific evidence of the improved conditions for wild animals to manifest their natural behavior. For instance, an article published in Science (Derryberry et al. 2020) addressed how the reduction of noise pollution in the San Francisco Bay allowed local birds to communicate better and meet more optimal conditions for mating, a study that was then picked up by the media (Hernández-Bonilla 2020). These journalistic depictions are significant not so much because they referred to sightings per se, but because the narratives themselves were exploring new ways through which to make the nonhuman animal visible within what seemed like a helplessly anthropocentric apparatus. Indirectly, such representations informed multispecies ethnographies and perspectives that revolve around "how a multitude or organisms' livelihoods shape and are shaped by political, economic, and cultural forces" (Kirksey and Helmreich 2010, p. 545). In this sense, nonhuman animality has the potential to be conceived and assimilated not as dichotomous from human cultures, but as embodiments that conceptually and spatially participate in the horizontal or the "rhizomatic" (Deleuze and Guattari [1980] 1987, p. 11) articulation of a bios of living organisms that range from cells, molecules, viruses, and microbes to plants, fungi, and animals. What the absence of humans visibly pictured and exposed was the artificiality of hierarchical binarisms built upon anthropocentric cultural constructs, all the more emphasized by coronavirus' infection of human and nonhuman animal vectors alike.

At the same time, however, ridding media discourses of binarisms and dichotomies still proved to be a quixotic gesture in many ways. The way the sightings of nonhuman animals were framed operated upon a discourse of authenticity, the narrative being one of an extra-human world that had been given a "breather" with human confinement, and that served as a hopeful reminder that nature could be recovered. Admittedly, these discourses that revised the embodiment of nonhuman animals had much to do with the aesthetic values that Western culture places on wildlife symbolism (and perhaps, especially, the United States with its historical dependency on the notion of wilderness for the proclamation of a national identity (Nash [1967] 2001)). As Isenberg notes, "[w]ildlife ennobles us; it may even be our salvation. But its values are those we ascribe to it, and the benefits of preserving wildlife accrue to us, too" (Isenberg 2002, p. 60). The cultural construct of wildlife and wilderness is aesthetically based on an alleged heterogeneousness with human participation. Tiger King showed, on the other hand, the full perversion of human intervention, as nonhuman animals were caged and commodified into profitable items made to lead miserable lives. From breeding, cub-petting, declawing, and poor nutrition and veterinary care to actual dispensation of individuals by shooting, the amount of cruel and barbarous practices that the series revealed presented a stark contrast to the wildlife that was otherwise peppering the media with reports on how they took the streets.

Simultaneously, the media coverage that dealt with the disastrous consequences of human interference with wildlife and natural habitats revolved mostly around the alarm caused by wet markets in China and Southeast Asia. Scientific hypotheses on the nonhuman animal hosts (bats and pangolins) and the contagion to humans through their ingestion (or the ingestion of domestic animals that had been exposed to the diseases of wild ones in such markets) triggered an array of discussions fueled by different types of passions. After all, "virus is not just what we talk about, it is how we talk about it" (Gray 2021, p. 93). Conspiracy theories met with the burgeoning xenophobia and racism of voices (infamously including that of President Donald Trump) eager to publicly condemn China as the sole culprit of the disaster. Hooper et al. noted how the Mail and The Sun basked in xenophobic and racist reporting, and utilized nonhuman animals to further encourage such views. Referring to the Mail, they write that "[t]he paper expressed concern for animals, but that concern usually served as a tool to berate the Chinese as the cause of Britain's problem with the virus" (Hooper et al. 2021, p. 8). These hierarchical antinomies that continued to separate white Western identity from Asian "otherness" ran parallel to the 
anthropocentric placement of nonhuman animals as the minor casualties of the pandemic, equating the long-established correlations between racism and speciesism and precluding the abovementioned realm of multispecies bios.

More educated perspectives, on the other hand, identified the source of the problem not as a Chinese one, but as a human one: in his New York Times article significantly titled "Our Cruel Treatment of Animals Led to Coronavirus", David Benatar (2020) claimed that the transmission of zoonotic diseases did indeed emerge from the unsanitary conditions of East Asian wet markets and the probable consumption of wild animals, but that these circumstances were part of a wider, global practice resulting from a brutal commodification of food animals that led to both profound abuse and public health hazards. This connectedness between Eastern and Western practices proved rather difficult for the animal rights movement to deal with at a discursive level. The direct call for the disappearance of wet markets (Singer and Cavalieri 2020; Bassey and Eyo 2020) became commonplace amongst animal advocates and internet users who had only just learned about the existence of such markets. Somewhat in line with the abovementioned study by Spiehler and Fischer (2021), Chang and Corman note that many animal advocacy organizations fell back into a rhetoric that came dangerously close to a racist privileging of certain issues over others: "The foregrounding of wet markets as the single origin and sole propagator of problems related to the pandemic prevents us from pairing our critiques with a strong anti-racist commitment" (Chang and Corman 2021, p. 61).

The massive coverage of what wet markets were and how they operated led public opinion to the belief that meddling with wildlife could have devastating effects for humans. The narrative became one of human hubris and anagnorisis- the awakening to the realization that nature could not ultimately be controlled, and that there was something inherently immoral (even if for anthropocentric reasons) in the processing and consumption of wildlife. In this light, Scheible questions the connections that audiences could make between their own confinement, the caging of wild tigers, the imprisonment of Joe Exotic, and the caged pangolins in Wuhan's Huanan Seafood Wholesale Market. He leaves the question unanswered, and shifts the focus onto the damage caused by the carbon footprint left by the millions of viewers of Tiger King, rendering the media as an agent in the "ailing allegory" (Scheible 2020, p. 570).

Beyond this undeniable damage to the environment, I would argue that growing knowledge and awareness of wet markets and the devastating effects of unchecked and unethical interventionism over natural habitats and wildlife rang well with the lingering motifs of regret and guilt that now and again troubled some of the docuseries characters. Especially in the closing of the final episode of the first season, the narrative becomes one in which the victimhood of the wild animals serves as a haunting reminder of the active role that one plays in perpetuating exploitation and cruelty. Erik Cowie, an employee at the GW Zoo, expresses his sense of having betrayed several tigers when Joe Exotic came to their execution: "Y'know, those cats trusted me. And so they could look me in the eye when they died. I was the guy that was right there. That means a minute to me. A heavy minute" (Goode and Chaiklin 2020, Ep. 7, 11:40). Saff, another former employee, says of the endless feud: "Nobody wins. Everyone involved is a so-called animal advocate. Not a single animal benefitted from this war. Not a single one" (Goode and Chaiklin 2020, Ep. 7, 32:40). Even Joe Exotic himself comes off as somewhat sympathetic at the end of the seventh episode, in a rare moment of redemption in which he admits to the suffering he has inflicted on nonhuman animal individuals:

Are the animals happy? Who the hell knows? I finally moved my two chimpanzees last week. Probably one of the hardest days of my life. They sat in cages next to each other for over ten years. And we moved them to the Great Ape Center in Florida. And in two days they were out in a big yard hugging on each other. Did I deprive them of that for ten years? Yep. I deprived them of being chimpanzees. Did I do it on purpose? No, I was wrapped up in having a zoo. (Goode and Chaiklin 2020, Ep. 7, 36:35) 
These attitudinal vestiges recall the conversion narrative that, for instance, articulated Psihoyos's The Cove (Psihoyos 2009) through the figure of former-dolphin-trainer-turnedactivist Ric O'Barry. In the case of Tiger King, which is so heavily invested in "othering" the marginal rural white community that sustains these zoos, conversion narratives function as bridges to human redemption-paradoxically, one becomes "humanized" with the acceptance of personal responsibility for nonhuman animal captives. In the context of the pandemic, narratives of remorse and regret for our treatment of wildlife have played well (even if for purely anthropocentric interests) because they give the illusion that a lesson may have been learnt, and that reform of the system (abolishment or restrictive control and surveillance of how wildlife is sold and consumed in markets) is in place. The extent to which these beliefs may or may not be self-deluded is yet to be seen in long-term effects. Paula Arcari's (2021) eloquent study on the extent to which mainstream media has assimilated and legitimized critical animal perspectives after our collective revisionism of the objectification of nonhuman others suggests that little progress has thus far been made. Effective normalization of alternative ways through which to think about nonhuman others begins with the practice of non-normative discourses in dominant media that will directly or indirectly question our consent of speciesism.

Yet another topic that rang familiar was the easy expendability of nonhuman animal lives. The documentary made it a point to question Exotic's actual involvement in the murder-for-hire of Carole Baskin, suggesting that he may have been framed by his expartner, Jeff Lowe. To emphasize this hypothesis, it echoed the opinion that the charges on wildlife violations, which included Exotic's violent execution of five tigers, were strategically used by the prosecution in order to make up for the lack of evidence implicating him in the plotted murder. Against the backdrop of countless stories of the extermination of nonhuman animals to prevent the spread of coronavirus, these acts of cruelty deeply resonate once more within the narrative of the extreme consequences of human interference with domestic animals and wildlife.

In China, companion animals were reportedly rounded up for execution at a time when the World Health Organization claimed that there was no evidence to support the theory that the virus could be transmitted to pets (Macrae 2020; Thomson 2020). In addition, in Western nations such as the UK, the demand for companion animals to cope with the solitude of lockdowns led to "an increase in puppy farming, theft and smuggling of animals from abroad" (Fox 2020, section Panic-Buying Pets, para. 3), and to their subsequent abandonment once confinement was over and the responsibility of pet-caring dawned on irresponsible owners. Further evidence of the disregard for animal welfare came with the execution of fur animals in Spain, France, and especially in Denmark, which "euthanized" approximately 17 million minks (Frater 2020; Kesslen 2020). Uncontrolled panic came with the knowledge that a number of pets and nonhuman animals in zoos had contracted the virus from human vectors in Europe, the United States, and Asia, while, as Coman and Ancuta point out as recently as in 2021, "there is currently no evidence that animals are involved in the spread of the pandemic in the human population" (Coman and Ancuta 2021, p. 70). The senselessness of massive extermination of nonhuman animals in a gesture disguised as philanthropy certainly gives us pause, and Exotic's cruel dispensing of individual tigers stands as a clear metonymy of the vulnerability that nonhuman animals face with our collective consent to the existence of spaces of captivity.

When the senselessness and the guilt sink in, one may find solace in the occasional public reaction against the management of these spaces. The deliberate execution of captive wildlife in zoos or circuses has attracted considerable media attention, of course, since pre-COVID days. Scholars often recover the story of the public electrocution of the elephant Topsy in Coney Island in 1903 precisely because of what it has meant in terms of nonhuman animal representation in modern, capitalist media and with respects to technology (Nance 2013, pp. 184-86; Tobias 2013, pp. 292-313; Stallwood 2018). Bombastically publicized as a "murderous beast", Topsy's death seemed to have been of little moral regard except for a handful of sympathizers. More than one hundred years later, however, the narratives 
justifying the execution of zoo and circus animals were being questioned and actively campaigned against in social media. A famous case was that of the Copenhague Zoo's decision to "euthanize" an eighteen-month-old giraffe called Marius for being genetically undesirable for breeding, and then dissecting him in front of an eager audience that included children in order to stage a scientifically "educational" and teachable moment (Smith 2014).

A well-known pandemic story keeping up with this thematic tradition was the proposed resolution of the Neumünster Zoo in Germany to kill off several of the nonhuman animals in their facilities and even feed their corpses to other caged animals to avoid their starvation, as the zoo faced financial difficulties in the midst of the COVID-19 crisis. "Although this contingency plan was never implemented, it triggered worldwide media coverage and public consciousness regarding the dismissal of animal welfare. Subsequently, donations from around the world started to flood into the zoo" (Yin et al. 2021, p. 1426). These collective gestures in the interest of the welfare of nonhuman animals that have already been wronged in so many ways also speak to the emerging practice of connectivity ethics that the pandemic has instructed us in. As Cabalquinto and Ahlin (2021) point out, quarantine has educated human communities in the manifestation and expression of digital languages of self and social care, whereupon the need for connectivity and empathy has sensitized our affect towards others. As public discourses of care grow and evolve in online platform imagery and language, and as all subjects, regardless of gender, race, or species acquire an online identity that substitutes their physicality, we learn to acquiesce and integrate ourselves into all forms of otherness to which we are connected. From the confines of our home, and by navigating through the labyrinthic distractions of saturated media reports, we can maximize our potential for care-and concerning ourselves with the misery of nonhuman animals held in zoos is a most ethical start.

\section{Conclusions}

As an isolated, decontextualized documentary, Tiger King stands as a difficult series to categorize in terms of its controversial (mis)messaging of the dire situation of endangered wildlife, namely, tigers and large cats. The impact the show had in popular culture evinces in many ways the extent to which nonhuman animals continue to be regarded as marginal, and its compulsion to operate under the auspices of fast, formulaic entertainment was heavily targeted by critics who exposed the creators' lack of concern for the conservation issues at stake. However, watching and reexamining the documentary in light of the media discourses that it landed on upon its release allows us to understand the malleability of interpretation. This process of discursive contextualization is an active exercise of responsibility on the part of consumers of both media and wildlife. The object is not to salvage the sinking ship of the series itself, but to reassess the mechanisms by which society's manufactured consent of nonhuman animal exploitation operate. Popular culture products such as Tiger King present rare opportunities through which to analyze how mass consumption of anthropocentric narratives can be imploded from within, and how we can employ the media to train ourselves to reach beyond passive reception.

Funding: This research received no external funding.

Institutional Review Board Statement: Not applicable.

Informed Consent Statement: Not applicable.

Conflicts of Interest: The author declares no conflict of interest.

\section{Note}

Throughout this article, the term "wildlife" expressly refers to nondomesticated nonhuman animals that, unless forced into captivity, live in their natural habitats. 


\section{References}

Adams, Carol J. 2015. The Sexual Politics of Meat. A Feminist Vegetarian Critical Theory. New York and London: Bloomsbury. First published 1990.

Ali, Lorraine. 2020. Commentary. Tiger King confuses binge-watching 'Justice' with the real thing. That's a problem. Los Angeles Times. April 2. Available online: https:/ / www.chicagotribune.com/entertainment/ct-ent-tiger-king-problems-20200403-h3upo6jtrjaj7 awjiz36fr7mga-story.html (accessed on 28 September 2021).

Almiron, Núria. 2016. The political economy behind the oppression of other animals. Interest and influence. In Critical Animal and Media Studies: Communication for Nonhuman Animal Advocacy. Edited by Núria Almiron, Matthew Cole and Carrie P. Freeman. New York: Routledge, pp. 26-41.

Kip Andersen, and Keegan Kuhn, directors. 2014, Cowspiracy: The Sustainability Secret. Santa Rosa: A.U.M. Films.

Arcari, Paula. 2021. The covid pandemic, 'pivotal' moments, and persistent anthropocentrism: Interrogating the (il)legitimacy of critical animal perspectives. Animal Studies Journal 10: 186-239. [CrossRef]

Baker, Steve. 2001. Picturing the Beast. Animals, Identity, and Representation. Urbana and Chicago: University of Illinois Press. First published 1993.

Bassey, Samuel Akpan, and Ubong Ekpenyong Eyo. 2020. COVID-19 outbreak: Wet markets and the ethics of anthropoholism. Euromentor Journal 11: 148-66.

BBC. 2021. Rhino poaching in South Africa falls during COVID-19 lockdown. BBC. February 1. Available online: https://www.bbc. com/news/world-africa-55889766 (accessed on 26 October 2021).

Benatar, David. 2020. Our cruel treatment of animals led to coronavirus. The New York Times. April 13. Available online: https: //www.nytimes.com/2020/04/13/opinion/animal-cruelty-coronavirus.html (accessed on 24 October 2021).

Berger, John. 2009. Why Look at Animals? London: Penguin. First published 1980.

Bousé, Derek. 2000. Wildlife Films. Philadelphia: University of Pennsylvania Press.

Cabalquinto, Earvin Charles, and Tanja Ahlin. 2021. Care within or out of reach. Fantasies of care and connectivity in the time of the COVID-19 pandemic. In Viral Loads. Anthropologies of Urgency in the Time of COVID-19. Edited by Leonore Manderson, Nancy J. Burke and Ayo Wahlberg. London: UCL Press, pp. 344-61.

Chalasani, Radhika. 2020. Photos: Wildlife roams during the coronavirus pandemic. ABC News. April 22. Available online: https://abcnews.go.com/International/photos-wildlife-roams-planets-human-population-isolates/story?id=70213431 (accessed on 20 October 2021).

Chang, Darren, and Lauren Corman. 2021. Multispecies disposability: Taxonomies of power in a global pandemic. Animal Studies Journal 10: 57-79. [CrossRef]

Chris, Cynthia. 2006. Watching Wildlife. Minneapolis: University of Minnesota Press.

Coman, Cristin, and Diana Ancuta. 2021. Ethics of the human-animal relationship in the COVID-19 pandemic. Journal of Intercultural Management and Ethics 1: 67-75. [CrossRef]

Gabriela Coperthwaite, director. 2013, Blackfish. New York: Magnolia Pictures.

Coronavirus. 2020. Coronavirus: The world in Lockdown in Maps and Charts. BBC. April 7. Available online: https://www.bbc.com/ news/world-52103747 (accessed on 15 October 2021).

Deleuze, Gilles, and Felix Guattari. 1987. A Thousand Plateaus: Capitalism and Schizophrenia. Translated by Brian Massumi. Minneapolis: University of Minnesota Press. First published 1980.

Chris Delforce, director. 2014, Lucent. Australia: Aussie Farms.

Chris Delforce, director. 2018, Dominion. Australia: Aussie Farms.

Derryberry, Elizabeth P., Jennifer N. Phillips, Graham E. Derryberry, Michael J. Blum, and David Luther. 2020. Singing in a silent spring: Birds respond to a half-century soundscape reversion during the COVID-19 shutdown. Science 370: 575-79. [CrossRef] [PubMed]

Pippa Ehrlich, and James Reed, directors. 2020, My Octopus Teacher. Los Gatos: Netflix.

FAADA. 2020. La alimentación de las palomas durante el confinamiento. FAADA. April 28. Available online: https://faada.org/ actualidad-1262-la-alimentacion-de-las-palomas-durante-el-confinamiento (accessed on 23 October 2021).

Flood, Brian. 2020. Donald Trump Jr. says Tiger King star Joe Exotic's sentence seems "aggressive", jokes he'd lobby for pardon. Fox News. April 6. Available online: https://www.foxnews.com/entertainment/donald-trump-jr-tiger-king-star-joe-exotic-sentence (accessed on 6 October 2021).

Fokidis, H. Bobby. 2020. Commentary. Tiger King: Owning tigers is not conservation. Orlando Sentinel. April 8. Available online: https:/ / www.tribpub.com/gdpr/orlandosentinel.com/ (accessed on 28 September 2021).

Fox, Rebekah. 2020. Has COVID-19 changed our relationship with pets and other animals? Warwick Knowledge Centre. August 3. Available online: https://warwick.ac.uk/newsandevents/knowledgecentre/society/sociology/animals_and_covid19/(accessed on 24 October 2021).

Frater, James. 2020. Denmark plans to cull up to 17 million mink to stop mutated coronavirus. CNN. November 5. Available online: https:/ / edition.cnn.com/2020/11/05/europe/denmark-mink-cull-coronavirus-intl-hnk-scli/index.html (accessed on 21 October 2021).

Frost, Rosie. 2021. COVID-19 has been a "double-edged sword" for conservationists. Euronews. May 20. Available online: https: / / www.euronews.com/green/2021/05/20/covid-19-has-been-a-double-edged-sword-for-conservationists (accessed on 24 October 2021). 
Goode, Eric, and Rebecca Chaiklin. 2020. Tiger King: Murder, Mayhem, and Madness. TV Documentary Series-Season 1; Los Gatos: Netflix. Gray, Charles Hables. 2021. Virus is a language. COVID-19 and the new abnormal. Cultural Politics 17: 92-101. [CrossRef]

Grondin, Simon, Esteban Mendoza-Duran, and Pier-Alexandre Rioux. 2020. Pandemic, quarantine, and psychological time. Frontiers in Psychology 11: 1-6. [CrossRef] [PubMed]

Hanson, Elizabeth. 2002. Animal Attractions. Nature on Display in American Zoos. Princeton: Princeton University Press.

Chris Hegedus, and D. A. Pennebaker, directors. 2016, Unlocking the Cage. New York: Pennebaker Hegedus Films.

Denis Hennelly, and Casey Suchan, directors. 2019, The Animal People. West Hollywood: Birdstreet Productions.

Hernández-Bonilla, Juan Miguel. 2020. Las aves cantaron más bajo y se comunicaron mejor durante el confinamiento. El País. September 24. Available online: https:/ / elpais.com/ciencia/2020-09-24/las-aves-cantaron-mas-bajo-y-se-comunicaron-mejordurante-el-confinamiento.html (accessed on 18 October 2021).

Hoage, R. J., and W. A. Deiss, eds. 1996. New Worlds, New Animals: From Menagerie to Zoological Park in the Nineteenth Century. Baltimore and London: The Johns Hopkins University Press.

Hockenhull, Jo, Keith Squibb, and Amelia Cameron. 2021. How has the COVID-19 pandemic affected the way we access and interact with the countryside and the animals within it? Animals 11: 2281. [CrossRef] [PubMed]

Hooper, Jes, Thomas Aiello, and Kristine Hill. 2021. Portrayals of animals in COVID-19 news media. Anthrozoös, 1-22. [CrossRef]

Horak, Jan-Christopher. 2006. Wildlife documentaries: From classical forms to reality TV. Film History 18: 459-75. [CrossRef]

Isenberg, Andrew C. 2002. The moral ecology of wildlife. In Representing Animals. Edited by Nigel Rothfels. Bloomington: Indiana University Press, pp. 48-64.

Curt Johnson, director. 2007, Your Mommy Kills Animals. St. Paul: Indie Genius Productions.

Robert Kenner, director. 2008, Food, Inc. New York: Magnolia Pictures.

Kesslen, Ben. 2020. Here's why Denmark culled 17 million minks and now plans to dig up their buried bodies. The Covid mink crisis, explained. NBC News. December 2. Available online: https:/ /www.nbcnews.com/news/animal-news/here-s-why-denmarkculled-17-million-minks-now-plans-n1249610 (accessed on 24 October 2021).

Kirksey, S. Eben, and Stefan Helmreich. 2010. The emergence of multispecies ethnography. Cultural Anthopology 25: 545-76. [CrossRef]

Kluger, Jeffrey. 2020. What astronauts can teach us about isolation and quarantine. Time. March 22. Available online: https: / / time.com/5807225/astronauts-isolation-quarantine-coronavirus/ (accessed on 16 October 2021).

Lagerwey, Jorie, and Taylor Nygaard. 2020. Tiger King's meme-ification of white grievance and the normalization of misogyny. Communication, Culture $\mathcal{E}$ Critique 13: 560-63. [CrossRef]

Lopez, Kristen. 2021. “Tiger King" season 2: Ugly villainy dominates Netflix's shameless double down on Joe Exotic saga. IndieWire. November 18. Available online: https:/ / www.indiewire.com/2021/11/tiger-king-season-2-review-netflix-1234680314/ (accessed on 20 November 2021).

Loy, Loredana. 2016. Media activism and animal advocacy. What's film got to do with it? In Critical Animal and Media Studies: Communication for Nonhuman Animal Advocacy. Edited by Núria Almiron, Matthew Cole and Carrie P. Freeman. New York: Routledge, pp. 221-33.

Macrae, Grace. 2020. Coronavirus: Chinese "round up and execute" pet dogs despite them NOT spreading the virus. Express. February 21. Available online: https://www.express.co.uk/news/world/1245331/Coronavirus-latest-Chinese-officials-execute-dogscarry-disease-china-wuhan (accessed on 20 October 2021).

Malamud, Randy. 1998. Reading Zoos. Representations of Animals and Captivity. New York: New York University Press.

Malamud, Randy. 2012. An Introduction to Animals and Visual Culture. Basingstoke and New York: Palgrave Macmillan.

James Marsh, and ir, directors. 2011, Project Nim. London: Red Box Films.

Liz Marshall, director. 2013, The Ghosts in Our Machine. Toronto: Ghosts Media.

Martin, Nik. 2020. Pigeons at risk of starvation over coronavirus empty streets. DW. March 31. Available online: https://www.dw. $\mathrm{com} / \mathrm{en} /$ pigeons-at-risk-of-starvation-over-coronavirus-empty-streets/a-52965011 (accessed on 23 October 2021).

Matthews, Alexander. 2020. The wild animals at risk in lockdown. BBC. May 21. Available online: https://www.bbc.com/future/ article/20200520-the-link-between-animals-and-covid-19 (accessed on 29 October 2021).

Mills, Brett. 2010. Television wildlife documentaries and animals' right to privacy. Continuum: Journal of Media $\mathcal{E}$ Cultural Studies 24: 193-202. [CrossRef]

Mills, Brett. 2012. The animals went in two by two: Heteronormativity in television wildlife documentaries. European Journal of Cultural Studies 16: 100-14. [CrossRef]

Mills, Brett. 2017. Animals on Television. The Cultural Making of the Non-Human. London: Palgrave Macmillan.

Mitman, Gregg. 2009. Reel Nature. America's Romance with Wildlife on Film. Seattle and London: University of Washington Press.

Molloy, Claire. 2011. Popular Media and Animals. Basingstoke and New York: Palgrave Macmillan.

Shaun Monson, director. 2005, Earthlings. Malibu: Nation Earth.

Nance, Susan. 2013. Entertaining Elephants. Animal Agency and the Business of the American Circus. Baltimore: The Johns Hopkins University Press.

Nash, Roderick Frazier. 2001. Wilderness and the American Mind, 4th ed. New Haven and London: Yale Nota Bene. First published 1967.

National Geographic en Español. 2020. National Geographic en Español. May 6. Available online: https://www.ngenespanol.com/ animales / avistan-a-un-zorro-en-una-de-las-calles-centrales-de-londres/ (accessed on 19 October 2021). 
Nuwer, Rachel. 2020. Why Tiger King is not Blackfish for big cats. The New York Times. April 9. Available online: https:/ /www.nytimes. com/2020/04/09/science/tiger-king-joe-exotic-conservation.html (accessed on 25 September 2021).

Orange, Michelle. 2020. The art of watching: Looking at animals looking at us. VQR. Available online: https://www.vqronline.org/tvfilm-criticism/2020/06/art-watching (accessed on 23 September 2021).

Louie Psihoyos, director. 2009, The Cove. Los Angeles: Participant Media.

Louie Psihoyos, director. 2018, The Game Changers. ReFuel Productions.

Amy Schatz, director. 2013, An Apology to Elephants. New York: HBO.

Scheible, Jeff. 2020. Tiger King as accidental allegory. Communication, Culture \& Critique 13: 568-70. [CrossRef]

Singer, Peter, and Paola Cavalieri. 2020. The two dark sides of COVID-19. Project Syndicate. March 2. Available online: https: / / www.project-syndicate.org/commentary/wet-markets-breeding-ground-for-new-coronavirus-by-peter-singer-andpaola-cavalieri-2020-03 (accessed on 22 October 2021).

Smith, Roff. 2014. Giraffe killing at Copenhaguen Zoo sparks global outrage. National Geographic. February 12. Available online: https:/ / www.nationalgeographic.com/science/article/140210-giraffe-copenhagen-science (accessed on 16 October 2021).

Spiehler, Alyse, and Bob Fischer. 2021. Animal agriculture, wet markets, and COVID-19: A case study in indirect activism. Food Ethics 6: 1-20. [CrossRef] [PubMed]

Spurlock, Morgan. 2004. Super Size Me. Los Angeles: Roadside Attractions.

Stallwood, Kim. 2018. Topsy: The elephant we must never forget. In Animal Biography. Re-Framing Animal Lives. Edited by André Krebber and Mieke Roscher. Cham: Palgrave Macmillan, pp. 227-42.

Ali Tabrizi, director. 2021, Seaspiracy. Los Gatos: Netflix.

Taylor, Nik. 2016. Suffering is not enough: Media depictions of violence to other animals and social change. In Critical Animal and Media Studies: Communication for Nonhuman Animal Advocacy. Edited by Núria Almiron, Matthew Cole and Carrie P. Freeman. New York: Routledge, pp. 42-55.

Temple, James. 2019. The 2010s were another lost decade on climate change. MIT Technology Review. December 24. Available online: https:/ / www.technologyreview.com/2019/12/24/131392/the-2010s-were-another-lost-decade-on-climate-change (accessed on 18 October 2021).

The Guardian. 2020. The urban wild: Animals take to the streets amid lockdown-In pictures. The Guardian. April 22. Available online: https: / / www.theguardian.com/world/gallery/2020/apr/22/animals-roaming-streets-coronavirus-lockdown-photos (accessed on 20 October 2021).

Thomson, Billie. 2020. Chinese officials "round up and execute villagers' pets to stop the spread of coronavirus" despite WHO experts saying the disease cannot be spread to animals. Mailonline. February 20. Available online: https://www.dailymail.co.uk/news/ article-8024787/Chinese-officials-continue-beat-dogs-death-fighting-coronavirus.html (accessed on 20 October 2021).

Tobias, Ronald B. 2013. Behemoth: The History of the Elephant in America. New York: Harper Perennial.

Orlando von Einsiedel, director. 2014, Virunga. Los Gatos: Netflix.

Way, Albert G., William Thomas Okie, Reinaldo Funes-Monzote, Susan Nance, Gabriel N. Rosenberg, Joshua Specht, and Sandra Swart. 2020. Roundtable: Animal history in a time of crisis. Agricultural History 94: 444-84. [CrossRef]

Yin, Duo, Quan Gao, and Hong Zhu. 2021. Rethinking wildlife tourism and conservation during the COVID-19 pandemic: An animal ethics perspective. Society \& Natural Resources 34: 1423-29. [CrossRef]

Zellmer, Amanda J., Eric M. Wood, Thilina Surasinghe, Breanna J. Putman, Gregory B. Pauly, Seth B. Magle, Jesse S. Lewis, Cria A. M. Kay, and Mason Fidino. 2020. What can we learn from wildlife sightings during the COVID-19 global shutdown? Ecosphere 11: 1-9. [CrossRef] [PubMed] 